\title{
Biography and Life-Writing
}

\section{Christopher Wiley}

Musical culture was indebted to biography throughout the long nineteenth century. It played an important role in the establishment and perpetuation of the musical canon, reinforcing the newly emerged aesthetic of the Great Composer and shaping the reception history of specific subjects by setting forth their claim to the limited cultural ground available (Wiley 2003). Biographical writing therefore reflected major pan-European developments in musical thinking, such as the shifting conception of music from a spontaneous, ephemeral entity to a fixed work (Wiley 2008). At the same time, it remained sufficiently locally sensitive to the values cherished by specific times and places, encompassing, for instance, the preoccupation with evolutionist thought in late Victorian Britain (Zon 2017, 191-225). Narratives of the lives of composers and musicians provided a convenient lens through which to view music history more broadly, while musical biography as a genre maintained a strong relationship with corresponding intellectual activities such as music criticism.

One facet of biography’s influence within nineteenth-century culture concerns the extent to which it yielded foundations for modern musicology, not least through the undertaking of “definitive” multi-volume lives that set the course for subsequent research including Chrysander’s on Handel (1858-67) or Spitta’s on Bach (1873-80). Jolanta T. Pekacz has discussed the nature of musical biography as having been "shaped by the nineteenth-century origins of the discipline of musicology as a product of modernity” $(2004,47)$, noting that pioneering figures such as Adler and, before him, Chrysander both made significant contributions to the biographical project, even as they advocated a combination of quasi- 
scientific and music-analytical approaches that seemed to downgrade the investigation of composers' lives to a subsidiary position limited to fact-based rather than evaluative epistemologies. Nor was the trend of antiquarians undertaking studies of unprecedented, monumental scope with the aim of producing landmark texts for posterity by any means confined to the Austrogermanic epicentre of the establishment of the modern discipline. In France, for instance, Fétis’s production of both a pivotal biographical dictionary (1835-44) and an unfinished general history of music (1869-76), each in several volumes, are indicative of the intertwined relationship between music history and biography, placing them at the origins of ethnomusicology given that the scope of Fétis’s enquiry extended beyond the European canon. Emblematic of such endeavours to write "definitive" lives and lasting historical texts was the aspiration of certain writers to correct the documentary record in terms of factual accuracy and previous portrayals of their subjects, not least Thayer's (1866-79) unraveling of the extensive biographical myth-making of Beethoven’s secretary, Schindler (1840, 1860). Typically the result of years or even decades of comprehensive research, a notable number were abandoned or remained unfinished at their author's death.

At the other end of the spectrum, the nineteenth century also witnessed the proliferation of smaller, accessible volumes on a range of musicians. In Continental Europe, among the best known examples of such "popular” biography include the writings of Marie Lipsius (under the pseudonym “La Mara”) as well as Nohl’s various books on Mozart and Beethoven published since the 1860s (Solomon 2001, 599). But these authors were exceptional for their historically enduring value; many other texts were intended for more immediate consumption by wide communities of "lay" readers and musical amateurs, and hence often possessed much shorter shelf lives. Typically they were produced with the aim of educating as well as entertaining their 
reader, thereby nurturing the broad social movement of self-improvement that emerged in the course of the century. Jonathan Rose (2001, 131-6), for instance, has discussed the activity of J.M. Dent, especially the flagship “Everyman’s Library” series, as illustrative of publishing houses' servicing of the needs of British working-class autodidact culture; that Dent founded the enduring “Master Musicians” series (Wiley 2003, 2008) places it close to the heart of Victorian musical biography. The education provided by texts of this nature partly took the form of supplying accessible information to members of the general public concerning the output of their subjects, which alone represented an important contribution to the cultivation of musical knowledge in an era in which access to performances and scores was inevitably limited, particularly outside of major cultural centres such as London, Paris, and Vienna. Moreover, within the hagiographical climate of the nineteenth century epitomized by Carlyle’s On Heroes, Hero-Worship, and the Heroic in History (1841), such biographies also functioned to offer their readers moral and ethical instruction, leading to the establishment of the genre of the "exemplary life,” whose whitewashed subjects embodied socially idealized, respectable conduct that the common reader was implicitly expected to emulate in order to better themselves.

Traditional narratives of musical biography have pointed towards John Mainwaring’s temporally anomalous Memoirs of the Life of the Late George Frederic Handel (1760), and its migration to Germany the following year in Mattheson's translation, as the earliest exponent of the fully-fledged genre. Nonetheless, it was not until the decade around the turn of the nineteenth century that musical biography truly asserted itself, through a series of writings on Mozart and subsequently Haydn. (To aid the navigation of musical biography’s complex chronology, a 
timeline of major publications of the long nineteenth century has been appended to this chapter. ${ }^{1}$ ) Some of the first took the form of "reminiscence biographies" by an author acquainted with their subject to a greater or lesser extent; the earliest fully-fledged texts on Haydn, by Griesinger (1810) and Dies (1810), are often considered as a pair, while Wegeler and Ries (1838) jointly published their recollections on Beethoven. The century also soon saw the historical recovery through the medium of biography of composers of past epochs, including Palestrina (Baini 1828) and Giovanni Gabrieli (Winterfeld 1834). Lenneberg (1988, 107-11) has indicated the significance of this development in the genre for its dependence on archival research in place of witness testimony; such endeavours additionally served to aid the formation of the musical canon and the establishment of its historical starting-point. Probably the most important public “rediscovery” of the early nineteenth century, however, was that of J.S. Bach; Forkel's landmark text (1802), the product of some decades' work and a key component of the wider Bach revival, followed in the footsteps of his seminal writings on music history and theory, hence cementing the depth of the relationship between them from a formative stage.

Ira Bruce Nadel (1984) has identified the nineteenth century as the time at which biography as a genre became both professionalized (67-101) and institutionalized (13-66). The former distinction is blurred in the case of life-writing on music, which has benefitted throughout its history both from the involvement of the leading musical authorities of the day and from interested connoisseurs whose primary field of activity lay elsewhere. While Griesinger’s connection with the music business is evident from his longstanding role as Haydn's liaison to Breitkopf and Härtel, the title page of Dies’s reminiscences of the composer described him

\footnotetext{
For the sake of brevity, short citations for many of the historical texts (pre-1930) referenced in this chapter have been incorporated within the timeline instead of being added to the reference list. The timeline, much like the main discussion, aims to be illustrative (and fairly broad-brush) rather than exhaustive.
} 
modestly as “Landschaftmahler” (“Landscape-painter”) (Gotwals 1963, 67, 69). Some of the genre's most renowned contributors, such as Stendhal, were prolific or noteworthy writers in other realms of the literary profession (for instance, in fiction or non-arts biography), whose activity nonetheless extended into music history and criticism. Nissen’s principal qualification for producing his milestone biography of Mozart (1828) was being the second husband of his subject's widow, yet he established within musical writing the two-volume format that became a staple of the nineteenth-century life and letters as well as a precursor for the aforementioned “definitive” biography. Jahn’s career as a university professor specializing in classics, philology, and archaeology is historically important for explicitly connecting musical biography with classical mythology through his monumental life of Mozart (1856-9) (Wiley 2008, 22), unprecedented at the time for its scope. George Grove famously reached music and academe by way of civil engineering, via a fifteen-year tenure as editor of Macmillan’s Magazine. The involvement in the biographical project of critics and reviewers, minor composers, authors of music appreciation texts, early musicologists, public lecturers, and, in time, also broadcasters made possible the development of the life-and-works model in the course of the century, sharing an intellectual heritage with the parallel emergence of the programme note through Grove and the Crystal Palace concerts (Bashford 2003; Bower 2016).

Biography’s institutionalization within the field of music, meanwhile, primarily took the form of two major nineteenth-century manifestations. First, the inauguration of monumental multi-volume biographical dictionaries of encyclopaedic scope, notably those written and overseen by Schilling (1835-42), Fétis (1835-44, 2/1860-5), Grove (1878-90), and Eitner (1900-4). These were the logical successors of precursory publications, conceived on a smaller scale but nevertheless significant for their scope, masterminded by Gerber (1790-2, 2/1812-4), 
Choron and Fayolle (1810-1), and Sainsbury (1825) earlier in the century. Second, the collection of individual composer biographies into book series, thereby establishing canons whose constituency reveals much about both the composers and the prevailing sensibilities of the times and places in which they were produced. The "Great Musicians” (1881-90) and "Master Musicians” (1899-1906) series in Britain, “Les musiciens célèbres” (from 1905) in France, and "Berühmte Musiker” (from 1897) in Germany are all indicative. A related phenomenon that lay halfway between the two was the collected biography, in which different composers were presented in a series of chapters within a single publication. Works of this nature, such as Parry's Studies of Great Composers (1886), offered the reader both a digestible sketch of an individual within the context of a solitary essay, and a piecemeal impression of music history through the lives of a select handful of revered figures when viewed across the book as a whole.

One seemingly inevitable consequence of the nineteenth-century proliferation of musical biography was the phenomenon of composers writing about their own lives. In an analogous manner to reminiscence biography given its dependence on witness testimony, autobiography crucially provided an authoritative documentary source capable of shaping the subject's image thereafter, potentially doubling as a pre-emptive attempt to condition their long-term reception in advance of biographical treatment by others who might not have been inclined to view them so charitably. Lenneberg $(1988,18-37)$ has drawn attention to the accretion of a significant precursory tradition of self-narration in the form of eighteenth-century lexicographical practices of soliciting contributions directly from the musicians in question. Of the many composers and, indeed, performers to have turned their hand to autobiographical writing in the long nineteenth century, the most frequently cited are surely Berlioz (1870) and Wagner (1865-80); yet even in these instances the generic positioning is far from clear-cut, in that Berlioz's output would be 
more properly regarded as memoirs written in the nineteenth-century French mould, while Wagner's autobiography was in reality dictated to his wife and, like Berlioz's, published only posthumously (as late as 1911). Berlioz, through the elaborate programme note associated with his ground-breaking Symphonie fantastique (1830), also became a figurehead for the understanding that developed during the century that music might itself be interpreted for its autobiographical content. This concept gained sufficient momentum that critics became increasingly eager to apply similar strategies retroactively to the music of earlier composers, notably Beethoven, within a range of biographical writings (Bonds forthcoming).

The scope of life-writing on music was such that it assumed a rich variety of interconnected forms in the course of the nineteenth century in addition to fully-fledged volumes and dictionaries. Both Bach and Mozart biography were indebted to extensive obituary notices respectively, Bach and Agricola (1754) and Schlichtegroll (1793) - which have set the agenda for much subsequent discourse on their respective subjects. The relationship between musical biography and the periodical was established early in the history of the genre, with texts such as Griesinger's on Haydn having originally appeared in serialized form (in this case, in the Allgemeine musikalische Zeitung in July-September 1809) before being published in its entirety as a book. Biographical writings flourished in the popular press, in which articles recounting episodes in a composer's life could be relied upon conveniently to fill spare column inches when required. Their vast potential to stir the public imagination made them ideal candidates for republication or later translation, hence furthering their dissemination and prolonging their currency. Personal documents such as correspondence and diaries also came be collected and edited in dedicated volumes as part of the burgeoning body of biographical literature, in natural consequence of the quasi-archival function fulfilled by the flourishing "life and letters" format 
and the "definitive” biography - and, in a very real sense, as modes of autobiographical narrative in themselves. Since they were typically not produced for any purpose other than private consumption, their publication risked negatively influencing composers’ posthumous image through presenting them in ways that may not retrospectively have been desirable, or even necessarily sensitive to the very people they portrayed. Issues of censorship and veracity were therefore raised in respect of such collections as Beethoven's conversation books, which were allegedly doctored and selectively destroyed by Schindler, and Liszt’s letters, which La Mara heavily edited for publication in multiple volumes around the turn of the twentieth century.

In light of the myriad possibilities for academic engagement with musical biography as a rich source of information about the reception history of a given subject within specific intellectual communities (Wiley 2008), as well as their associated cultural assumptions and tendencies, much research has been conducted in the field in recent years, partly in the wake of the New Musicology, which brought about a renewed emphasis on contextualization within the discipline (Wiley 2010). Nonetheless, scholarship has hitherto tended to focus predominantly on single-composer studies, exploring such matters as changing perspectives on the subject over the years, the lineage of their life-writing, and the tropes, images, and mythologies with which they have become associated in different times and places (whether such research seeks to serve the purpose of cultural analysis, correction of past errors, or outright revisionism), as well as on enduring biographical projects by key authors. Correspondingly, the "popular” texts that often enjoyed wider circulation and readership, and hence had more immediate potential to perform significant cultural work in their own day, have too often been given relatively short shrift in favour of biographical undertakings of more enduring historical value; and where studies have encompassed "popular" biographies, they have typically examined those authors and projects 
that have exceptionally stood the test of time, such as the writings of La Mara (for example, Deaville 2006) or the "Master Musicians" series (Wiley 2003; Wiley forthcoming). Neither has previous research tended centrally to address the issue of musical biography as a genre, in which the spotlight falls not on any one particular composer so much as on the preoccupations and predispositions that have historically accrued more generally across life-writing in the field (Wiley 2008); and the nineteenth century itself is disproportionately under-represented, given its fundamental role in the establishment of modern musical thought, in a number of the booklength musicological publications (Lenneberg 1988; Wiley and Watt forthcoming).

The remainder of this chapter discusses two case studies that endeavour to elucidate manifestations of musical biography that have thus far been under-theorized in the scholarly literature, but which nevertheless offer distinctive examples that serve as instructive illustrations of many of the wider points raised in connection with life-writing and nineteenth-century culture. The first investigates the often overlooked genre of anecdote through adopting a survey-style approach to the Victorian values embodied in a compilation text by a prolific musical biographer of the period, Frederick Crowest's two-volume A Book of Musical Anecdote (1878); the other enables consideration of the specific issue of the role of women in life-writing on the Great Composers through close textual reading of a collected biography by an influential music critic, George P. Upton's Woman in Music (1880, 2/1886). Each therefore constitutes an act of lifewriting that encompasses a range of musicians, facilitating a wider picture to be formed than the focus on a single subject that traditionally characterizes musical biography, and expanding investigation beyond the realm of composers (on whom both the practice and the academic study of the genre have overwhelmingly been conducted) to encapsulate performers as well. While mindful of the importance of Continental European currents in musical biography, each case 
study crystallizes instead around "popular" Anglo-American discourse, a cultural framework that has benefitted from a greater level of continuity of, and fascination with, its biographical lineage than counterparts in countries such as Germany (Schlaeger 1995). These explorations lay the foundations for a concluding section that contemplates the legacy of historical developments in musical biography, in terms of the extent to which the intellectual tenets it embodied have been inherited by twentieth-century musicology.

\section{Anecdote in musical biography}

Musical biography has been indebted to anecdote from the outset. Bach’s obituary furnished history with five key episodes that have provided solid foundations for later life-writing on the composer; Rochlitz’s 27 anecdotes contributed to the Allgemeine musikalische Zeitung between 1798 and 1801, for all their fanciful embellishments, nonetheless represented an influential source widely disseminated through their translation and wholesale incorporation into subsequent biographical texts; and the early reminiscence biographies of Haydn and Beethoven inevitably adopted a primarily anecdotal vein. The provision of such stories in the course of biographical writing yielded a powerful means of lending the subject agency as a "real life" person while offering an idealized illustration both of their genius and their laudatory conduct. Some of the most famous themselves expanded over time into fully-fledged tales of mythic proportions (Wiley 2008, 20-178), but many others merely reflected entertaining episodes with which to captivate the reader.

While biographical anecdote served the important functions of fleshing out the narrative and maintaining the reader's interest within book-length texts, dictionary entries, and the popular press alike, it reached its apogee in dedicated collections such as Frederick Crowest's A Book of 
Musical Anecdote. Crowest (1850-1927), a prolific writer on music based in London who held a succession of editorial positions with major publishing houses, was a significant figure to late Victorian musical biography, not only by virtue of publications such as his essay collection The Great Tone-Poets (1874), biographies of Cherubini (1890, for the "Great Musicians" series) and Verdi (1897), and The Dictionary of British Musicians (1895), but also as editor of the earliest incarnation of the celebrated "Master Musicians" series (1899-1906), and contributor of its volume on Beethoven (1899) (Wiley 2008, 183-4). A Book of Musical Anecdote (1878) itself comprised over 500 numbered passages divided unevenly between its two volumes into four “Books,” featuring composers (212 anecdotes), singers (123), instrumentalists (75), and miscellaneous anecdotes (99); in practice there is some blurring between them, since many of the episodes retold in Book I properly concerned accomplishments in performance, while those pertaining to certain famous composer-instrumentalists (notably Liszt) appeared instead in Book III. $^{2}$ The collection's coverage was wide in terms of the range of different subjects (especially in the latter three Books) as well as the diverse representation of countries, spheres of activity, and epochs of music history; it concluded, for instance, with the medieval legend of King Richard I and Blondel (ii.292-4), while several episodes in Books III and IV relate to classical antiquity. While not wishing to fall into the same trap as much previous musicological scholarship of privileging life-writing on composers over that of other musicians, the focus of my discussion will inevitably fall disproportionately on Book I, which, in terms of size, is nearly as large as all of the others put together.

2 In the discussion that follows, parenthetical citations refer to Crowest (1878) unless otherwise stated, using the volume rather than Book number. 
The anecdotes contained in Crowest's opening Book are also the ones in which the author offered the greatest level of contextualization and evaluation. Whereas those of Books II and III are typically briefer and more concentrated on recounting the biographical episode in question, Crowest often introduced specific episodes in Book I (as well as the more discursive Book IV) with comment on the wider issues they exemplified, sometimes at such length that the person ostensibly at the centre of the story was all but eclipsed. Other of Crowest's numbered passages either covered parallel episodes in the biographies of two (sometimes more) subjects within the context of a single "anecdote," or explored a particular topic in relation to the lives of many different musicians. Occasionally, they crystallized not around specific figures at all, but around broader musical matters such as the significance of whether composers did or did not write at the keyboard (i.246-8), or the routines by which different singers sought to preserve their voices (ii.8-10).

Crowest's preface indicated that his primary aim was the provision of stories that "are all characteristic of the persons of whom they are told, and [...] furnish a glimpse of the private or lay side of musical celebrities not often successfully brought out amid the hard and dry facts of their biography" (page unnumbered). In that vein, each is given an engaging title such as "A Leg for a Life” (i.5) on Lully's untimely end, “A False Accusation” (i.90) on the rumours of Salieri’s having poisoned Mozart, or "A Nightingale’s Nest” on the childhood discovery of Jenny Lind (i.316). Some are remarkably concise (one of the shortest, on Handel [i.44], is just over five lines long) while others run for several pages covering multiple subjects; other than their arrangement into four Books and the occasional appearance of two adjacent anecdotes on the same musician, they are essentially self-contained and not presented in any immediately apparent over-arching order. Given the brevity of many coupled to the frequent changes of direction of wider spans of 
text, it is reasonable to suggest that Crowest's miscellany had much potential to hold the attention of the late Victorian autodidact (whether reading from cover to cover or skipping in and out of the volumes at will), and consequently to enhance their general musical knowledge. The narrative may consistently come across as quite bombastic in tone to a modern reader, consonant with tendencies in "popular" biographical writings of the time towards hyperbole, exclamation, and hagiography; the insistent use of the first-person plural lends the text an air of authority, even as it decried "that section of critics who claim a species of omniscience" (i.216).

According to the work's subtitle, Crowest drew his anecdotes "From every available Source.” His publication thus fell within broader nineteenth-century traditions, very visible in the field of music, of newly penned accounts being heavily based on previously established biographies, even if, as noted, they might have been further embroidered by fresh authorial glosses. Given the limited regulation of copyright at the time, the phenomenon was so prevalent that certain early texts, including Sainsbury's Dictionary of Musicians (1825), were in reality largely assembled from pre-existing sources (Wiley 2008, 33-4); others constituted outright plagiarism, such as Stendhal's biography of Haydn and Mozart (1814), particularly in respect of Carpani’s 1812 text on the former (Wiley 2013, 202). For his part, Crowest indicated that many of the anecdotes he related were already well known, while some had not previously been told in print. At one end of the spectrum lay certain extremely familiar episodes that were already in wide circulation at the time; at the other, the author specifically vouched for several himself (for instance, i.132).

While acknowledging that "In the mass of anecdotes and gossip which collects round the biography of any celebrated person there may generally be found a stratum of 'fibs,' some of them given and repeated on the authority of intimate friends" (i.81), many of the tales that 
Crowest recounted have a certain air of hearsay, ascribed, if at all, to memoirs and witness testimony. Out of all the sources cited by name, Crowest seemed especially indebted to Kelly's Reminiscences (1826), mentioned in multiple anecdotes; he also explicitly drew on the Englishlanguage versions of standard biographical texts including Forkel on Bach (trans. 1820), Schoelcher on Handel (1857), and Kreissle on Schubert (trans. 1869), amongst many others. Several of Crowest's stories were taken from periodicals of the day including Macmillan's Magazine, The Spectator, and The Musical World. He evidently held the landmark British histories of music in high regard, his anecdote on Hawkins and Burney (i.105-6) being strikingly out of place in a section otherwise dedicated to composers; and several references are made to Cox’s recently published two-volume Musical Recollections (1872).

Perhaps inevitably for Victorian biography, the musician most strongly represented in Crowest's miscellany is Handel, the subject of some 30 anecdotes in whole or in part, not counting additional fleeting mentions. The next most frequently encountered are Haydn and Beethoven, both discussed in connection with approximately 20 biographical episodes, followed by Mozart, Cherubini, Rossini, and Mendelssohn, who are featured in a dozen or more each of Crowest's stories. Coverage of performers is significantly more diverse, with Maria Malibran, who made several momentary appearances in Book I, most prominent in subsequent sections, with over ten passages devoted to her; having become a legendary figure for her popularity on the earlier nineteenth-century operatic stage and her premature demise, Crowest commented that "any collection of musical anecdotes would be singularly defective without some few scenes from the life of this typical artist” (ii.61). Luminaries of the Handelian stage, notably Farinelli, were also repeatedly drawn to the reader's attention; and Crowest offered several consecutive anecdotes on both Paganini (the most commonly featured person in Book III) and Moscheles, the 
latter quoting generously from the recently translated biography written by his wife (1873). Conversely, Wagner and Verdi are conspicuous by their absence. The former seemed only ever to be mentioned in passing, Crowest having expressed negativity towards both the composer and the "Music of the Future" more broadly (for instance, i.260; ii.60, 194). The general omission of Verdi is more surprising, not only because Crowest recognized him as "the most distinctly popular of modern composers" (i.178, italics in original) but also since he was, as noted, the subject of a subsequent biography by the same author. In this respect, the consideration that Crowest gave to Cherubini in his collection, benefitting from Bellasis's timely volume (1874), is more representative of his subsequent contribution to composer life-writing. Similarly, alignment was only partial with Crowest's prior activity in the field, The Great Tone-Poets being a collected biography of J.S. Bach, Handel, Glück [sic], Haydn, Mozart, Beethoven, Spohr, Weber, Rossini, Schubert, Mendelssohn, and Schumann, developed from a series of "popular" biographical articles for the Et Cetera magazine.

The extent to which Crowest showcased Handel and Haydn within his publication constitutes just one instance of the strongly Anglocentric leanings that are manifested throughout by way of promotion of Britain's unique musical culture. Within the context of an era of strong nationalist fervour, in which the genre of biography ideally served to celebrate a given country's greatest historical personages, the dearth of British figures among the Great Composers was a source of considerable tension for Victorian musical biography, in which native Continental European figures - not least the naturalized Handel, as well as Haydn and Mendelssohn, both of whose careers were indebted to England - instead came to be appropriated as surrogate national heroes (Wiley 2003). Crowest’s preoccupation with originality in music (i.29, 123-4, 188-92) was largely motivated by the need to defend Handel and Haydn against allegations of plagiarism, 
while certain of his passages explicitly addressed strong national traditions that lay largely outside the nineteenth-century European canon, such as the English glee school (i.25-6), organbuilding (i.35-6; cf. ii.244-5), and opera (i.156); he drew specific contrast between the apparent failure of the latter and the success of its French counterpart. Other of his anecdotes considered at length the challenges of English-language texts that did not ideally lend themselves to musical setting (i.151-4), and the relative incomprehensibility of English song as realized by certain foreign performers (ii.47-8). One led Crowest to remark “That Germany is the musician’s paradise, is perhaps one of the most widely spread of popular delusions” (i.256) in connection with an exploration of Great Composers (notably Mozart) having received little recognition in death. Another, comprising biographical vignettes of the succession of composers buried in Westminster Abbey from Purcell to Sterndale Bennett (the latter having died just three years before Crowest's text was published), yielded the codicil that such home-grown musicians will no doubt stand up favourably "even against the outrageous adaptations of the French and Italian schools" (i.57).

Yet Crowest's miscellany by no means limited itself to musical figures who either possessed strong British connections, or were otherwise well-known within the nation. For instance, he included half a dozen anecdotes on Grétry and nearly as many on Lully, while his only passage on Adolphe Adam noted that he had written "many compositions of which, at present, the English public are in profound ignorance” (i.212). Nonetheless, as many as four anecdotes were dedicated to Arne, and three to Purcell; and John Bull shared a passage on composing under “lock and key” with no lesser figure than Mozart, proving, in Crowest’s eyes, the falsehood of what he described as "the favourite taunt of foreigners that we are an utterly unmusical nation” (i.172). Only in a Victorian publication might we expect to find Balfe, about 
whom six anecdotes were written, to have been more heavily featured than any of J.S. Bach, Schubert, Berlioz, Chopin, Schumann, or Liszt, all of whose lives were richly embroidered with engaging stories that could easily have been retold for this purpose. Crowest even advanced a fanciful claim that Donizetti was of Scottish ancestry (i.109-10), while one of his longest anecdotes concerned the prodigious childhood of a musician as relatively inconsequential to Western music history as William Crotch (i.32-5).

Other themes that emerged from Crowest’s narratives represent familiar tropes more widely encountered across nineteenth-century European musical biography (Wiley 2008). Consonant with contemporaneous notions of musical geniuses having composed not to pander to the immediate tastes of the public but for posterity and the advancement of art, for example, Beethoven was identified as having written his works "not for an age but for all time” (i.16), given the detailed level of expressive nuance they embodied. Crowest repeatedly impressed upon the reader the notion that many of the great musicians lived in poverty $(i .37,196-8,276)$ and lacked the business sense that would have enabled them to employ their musical gifts merely for financial gain (i.45-7), but that they behaved charitably and generously towards others nevertheless (i.42-3). Commenting that "Genius seems like some plant that cannot flourish upon a rich soil," Crowest cited the penury endured by Beethoven, Mozart, Schubert, Bach, Rossini, Haydn, Weber, Spohr, and Gluck (in that order), before remarking, "Yet, see what these men have done!” (i.196-7). Elsewhere in his collection, several successive passages brought Malibran's supportive and charitable nature into sharp focus (ii.85-7), while an anecdote illustrating Paganini's benevolence is described as "perhaps the most touching” of all, and "thoroughly in character" (ii.132). 
In emphasizing such aspects of his subjects' biographies, Crowest was evidently mindful of the importance of supplying a moral education to the reader as well as a musical one, even overtly imploring the aspiring musician to "take to heart the lives and careers of the greatest composers. A perusal of the biographies of these men should teach those who read them wholesome lessons" (i.31). In this respect, he not only appeared to be writing for the purpose of furnishing the contemporary culture of autodidactism with suitable reading material, but also specifically promoting composers as being exemplary, thereby elevating the anecdotes of his Book I above those on other types of musician. In accordance with the Protestant work ethic, Crowest identified that the mere possession of talent was inadequate on its own to attain success; in his words, without the "Indomitable perseverance" needed to bring it to fruition, "the genius will soon die out” (i.187). Hence his sketch of Haydn's character highlighted the composer's industry, his methodical devotion to (and readiness for) his work, and the nature of his study as a "paradise of neatness" (i.20); these concepts seemed to be sufficiently noteworthy for the author exceptionally to provide a partial recapitulation some pages later (i.77-8). Moreover, Crowest insisted upon the value of making the most productive use of one's whole life, however short or long: one of his anecdotes even contextualized the prolific work-lists of Handel, Mozart, and Haydn with reference to the amount of time they had available to them (i.179-81). Rossini's premature retirement from composition conversely generated evident unease, since it was an element of his life for which the author endeavoured to offer explanation on more than one occasion (i.98-9, 197).

Crowest's A Book of Musical Anecdote was among the earliest of his many writings on music, appearing towards the start of an extensive engagement with the biographical project that was sustained well into the twentieth century. What makes this publication even more 
remarkable is that it was itself revised in a single volume, some 25 years later, as Musicians’ Wit, Humour, and Anecdote (1902), published by Scott (with whom Crowest was editor and general manager); paradoxically, it is simultaneously one of his first and last contributions to the genre. According to the author's preface, the result, undertaken "in order, mainly, to meet the requests of many known and unknown friends,” was “almost a new book” in itself (page unnumbered). Although the four-book structure of the original was retained, the revised collection was weighted still further in favour of Book I, which occupies well over half of the whole, indicative of the longevity of anecdotes on composers relative to those on other types of musician (even with the addition of more recently active performers such as Anton Rubinstein, Sims Reeves, Ignacy Jan Paderewski, and Clara Butt). Many of the familiar stories from the 1878 edition were reproduced with only minor emendations, and others were glossed to give them currency, streamlined to excise outdated material, or otherwise excerpted; but the volume's expansions were significant as well, yielding some 550 anecdotes in total, together with over 100 newly included illustrations by J. Philip Donne. Wagner was much more prominent in the revised version, featuring in over a dozen passages (not all of which cast him in a sympathetic light), as was J.S. Bach, while fully six anecdotes were devoted to Verdi. More locally relevant episodes such as the long interlude on William Crotch's childhood, as well as the biographical outlines of many of the English composers interred at Westminster Abbey, were tacitly removed, for which the greater prominence given to Arthur Sullivan only partially compensated.

Some instructive insight into the wider relationship between Crowest's literary pursuits and contemporaneous life-writing is offered by Harasowski’s (1967) comprehensive review of biographical narratives on Chopin, which touched on Crowest's A Book of Musical Anecdote in relation to three anecdotes recounted about the composer in its revised incarnation (1902, 45, 75, 
141-2), two of which were likely based on the biography attributed to Liszt (1852).

Harasowski's most major frustration appears to have been Crowest's repeated omission to cite his sources: despite the many broad indications of the literature with which he had engaged, inevitably Crowest did not conform to the more rigorous standards of referencing of the later twentieth century, having stated the precise origin of his information in less than one-fifth of instances in the original 1878 version and not infrequently supplying quotations without naming the author. Harasowski's verdict, that Crowest's volume therefore "cannot be regarded as a serious source for any musician’s biography” $(1967,258)$, was plainly stated. But that alone hardly exhausts the value of studying the text as a cultural artefact, which - not least given the author's impact on, and prominence within, the Victorian biographical project - provides an informative illustration of those musical and moral values that were cherished in later nineteenthcentury Britain, as well as of the considerable implications of anecdote for engaging the reader and constructing exemplary musical lives. Notwithstanding the limited longevity accorded to the average "popular" biography, many of which were targeted to specific reading communities and hence soon bore the hallmarks of their time and place of writing (Wiley 2003, 2008), its revision and republication a quarter-century after its initial appearance elevated Crowest's collection to a distinctive cultural position within intellectual culture for its rare staying power.

\section{Women in life-writing on the Great Composers}

Catherine Peters (1995) has advocated for the importance of biography's focusing not merely on the subject in contrived isolation, but also on the secondary characters whose influence on the more famous associate, and whose corresponding implications for their life story, may traditionally be overlooked. This is an issue especially significant to music, which had evolved as 
a fiercely male-dominated field by the nineteenth century, with little room in its emergent canon to accommodate anybody other than a select handful of exalted male figures. The role of women is therefore often confined to that of a background figure within life-writing on the Great Composers, and, as I have elsewhere shown, the genre thereby became complicit in women's historical effacement through its repeated casting of specific females in the passive role of muse to their attendant male genius, capable of inspiring that person to greater heights of artistry and productivity but not of undertaking such creative acts themselves (Wiley 2015).

This is certainly a pattern that emerges strongly from close reading of George P. Upton's Woman in Music (1880), a collected biography of eight Great Composers - J.S. Bach, Beethoven, Haydn, Mozart, Schubert, Schumann, Mendelssohn, and Chopin (in that order) - to which Handel, Weber, and Wagner were added for the second edition (1886). ${ }^{3}$ Upton (18341919), a pioneering music critic and journalist, enjoyed a longstanding association with the Chicago Tribune from the 1860s into the twentieth century that cemented his place within the city’s evolving cultural scene. His various books on music fell within the lineage of "popular" texts on music appreciation for the self-education of the concert-going public, and included volumes on the "standard" operas (1886, in its original edition), symphonies (1889), other concert repertory (1909), and song (1915), as well as his own recollections (1908), a handbook of musical biography (1910), and translations of Nohl’s lesser-known lives of Haydn, Liszt, and Wagner.

3 Through cross-referring the two different editions of Upton's text, I have satisfied myself that the interpretations offered in the following section are a faithful reflection of the original as well as its subsequent expansion. Page references supplied parenthetically in my discussion refer to the revised 1886 version, but all quotations are near-identical in both editions (excepting those from chapters newly contributed to the second). 
Upton's intentions in Woman in Music transcended the mere writing of biographical outlines of a series of composers per se: his focus fell more specifically on the exploration of their connections to particular females, and on the significance of those women to their lives, works, and productivity (205). It is therefore distinctive for its overlapping with the genre of relational biography (in which two subjects are explored in tandem for the developing connection between them) and, moreover, for seeking to trace analogous patterns across the lives of multiple musical subjects; its subtitle, “An Essay,” hints that the author viewed each chapter as part of a singular, overarching argument. Dedicated rather fittingly to his wife "As a Tribute to the friendship of a steadfast comrade, and as an acknowledgment of her helpful service,” Upton's volume was framed by an introductory outline of women's general influence on music and their absence among composers, and a concluding section on women as performers (to which he appended a list of women composers since the seventeenth century, and another of works with female dedicatees written by subjects featured in the main biographical chapters). The author accepted that the issue of the role of women in "encouraging" and "inspiring" the "finest works" of the Great Composers was the more prominent of the two, since their function as musical interpreters, especially of song, was already widely recognized (16).

Like Crowest before him, Upton was anxious to distance his study from the fanciful myth-making that had characterized earlier life-writing, and from the "medium of romances and rhapsodies that have been woven about the lives of composers [...] that have come down to us, and are implicitly believed, though they have no foundations to rest upon.” (17). Nonetheless, his essay seemed indebted to nineteenth-century stereotypes such as that of Bach as the underappreciated church musician earning a meagre living while raising a large family as part of an artistic dynasty. Upton's first biographical vignette established J.S. Bach’s need for a “sensible, 
practical, industrious, and economical woman" (38) who could manage the household in terms of both caring for the children and living frugally, thereby ensuring that his "musical labors were never disturbed” (39) by such day-to-day matters. His view was that by this token, both of Bach’s wives represented good companions for the composer; however, since Maria Barbara was not known to be musical, whereas Anna Magdalena is associated with significant amounts of his music, Upton therefore concluded that "the second marriage was the happier" (46). The same trope appears in reverse in the chapter on Mozart, which revolves around Aloysia and Constanze Weber. ${ }^{4}$ Upton's opinion was that Mozart may have wanted the former, but he needed the latter: Aloysia was the more musical of the two, but Upton held that Constanze possessed both a “deeper insight into music” and, crucially, a "rare tact in managing household affairs” (102), a point he reiterated for emphasis (109).

Upton's penchant for drawing comparisons between two women in the life of a single composer becomes idiosyncratic in those chapters in which one is identified as a positive influence on their associated protagonist's life and output, and the other a negative one. His biographical outline of Weber contrasted the composer's idealized union with his wife, Caroline Brandt, and his ill-fated relationship with Thérèse Brunetti. That on Wagner depicted his first wife, Minna Planer, as having not been a "helpmate” to him for having neither appreciated music nor the vocation for which he was destined (178) - a far cry from the "complete sympathy" he was said to have enjoyed with his second, Cosima, who "understood him, inspired him, and proved a blessing” (180). In the case of Chopin's life, Upton located both influences in a single

4 For consistency with Upton's volume and to avoid confusion, my discussion ordinarily cites the names by which female characters were known prior to marriage to their associated composer, even when they took their husband's surname thereafter. 
woman, George Sand, who, amongst all the women who frequented the composer's salon, constituted "at once his good and evil genius" (149).

Upton thereby portrayed George Sand as a "fatal necessity" (154) for Chopin, emphasizing that theirs was "a union of two natures with nothing in common, - most fatal of all mistakes” (159). In so doing, his work subscribed to nineteenth-century notions of the exemplary life with particular respect to relations (largely romantic, but also familial) between a man and a woman, thereby enforcing the prevailing social values and expectations of the day. The point seemed especially important to underline in the brief chapter on Wagner added for the second edition (his inclusion having presumably been at least partly in consequence of his having died in the period between the original and revised publications), doubtless by way of offsetting the challenging biographical territory of Cosima’s separation from her existing husband, Hans von Bülow: Upton even went so far as to claim that out of all of his case studies, "Never was there a more perfect companionship, perhaps,” than that between Wagner and Cosima (181). He employed similar sleight of hand in addressing Haydn's unsuccessful marriage to Maria Anna Keller in another of the volume's shorter chapters. Noting her lack of sympathy for the composer and his work, Upton was careful to identify that for his part, Haydn "always acted honorably” (89) during their separation, by ensuring adequate financial provision for her. Upton tellingly employed exactly the same vocabulary with respect to the women with whom Haydn was subsequently associated, for instance, commenting that "The place of his wife was very happily, but not very honorably, filled” by the already married Luigia Polzelli (90) and that, conversely, his close - but apparently platonic - friendship with Maria Anna von Genzinger was "honorable” for the significant influence she exerted on his compositional activity (95); he even put forward 
the far-reaching speculation that The Creation and The Seasons might be ascribed to this same source of inspiration.

Read collectively, the case studies of Woman in Music implicitly present marriage as something of an ideal to which to aspire. Upton's chapter on Schumann explored the composer's relationship with Clara Wieck almost exclusively, relegating other potential candidates for discussion, such as Ernestine von Fricken and Henrietta (sic) Voigt, to a couple of sentences towards the very end (136-7). By way of explanation, Upton offered that "Not one of these [other] attachments [...] specifically influenced him in musical production” (137); but since this claim aligns imperfectly with the list of female dedicatees of Schumann's works supplied in his own appendix (214-5), a more likely reason seems to have been the desirability of highlighting the centrality of the wife to the composer's biography. But such emphases presented Upton with considerable challenges when discussing those composers who remained bachelors, and, indeed, those whose lives yielded a relative dearth of relationships with women to begin with. The chapter on Beethoven, by far the longest of the volume's biographical vignettes, has the flavour of a fantasia on the women with whom the composer may or may not have been romantically associated (to which Upton noted that he could have added "many others" who did not receive mention [82]), culminating, not unexpectedly, in the (presumed) "Immortal Beloved.” The author employed various strategies by which to account for such absences. In Beethoven's case, borrowing another nineteenth-century stereotype, Upton held that Beethoven’s “deafness compelled him to retire within himself" (64), precipitating the withdrawal from society that might otherwise have enabled him to enjoy a successful marriage. Similarly, Upton rationalized Schubert's status as an "exception to th[e] rule" (121) with reference to his unattractive physical appearance, speculating that had these circumstances been different, "it is entirely probable that 
he might have married, and that [...] much of the sorrow of his life might have been avoided" (117). Nonetheless, Upton claimed that "the happiness of love" infused his song output "with the purest ideal feeling” (124), much as he indicated that Chopin’s music “bears trace on every page of woman’s love and influence” (161), and attributed “almost everything” of Mozart’s postmarriage output to Aloysia notwithstanding the comparative shortage of explicit dedications (110).

As Derek B. Scott $(2003,214)$ has observed, probably the most revealing chapter in this respect is the one on Handel. The life of the naturalized British composer was hardly suited to the focus of Upton's volume; however, Handel’s popularity in nineteenth-century Englishlanguage intellectual discourse, his celebration through biography as a home-grown talent in an era of nationalism, and his continued impact on English musical life were such that his omission from the first edition must have seemed incongruous. Scott rightly noted Upton's emphasis on the composer's "great love for the mother to whom he owed so much" (51), who supported his musical studies when his father did not and thereby prepared him for his vocation, as a familiar ploy to counterbalance the absence of romantic relationships in Handel's life. But this line of enquiry of itself accorded with those of other chapters: the theme of the mother who did "all in her power" to realize a young composer's musical potential also emerged from Upton's vignette on Wagner (178), while that on Mendelssohn confined itself to the "home circle" of "His mother, his sister, and his wife” (140) (even if the latter are its twin focal points), and, drawing on another familiar biographical trope, Helene von Breuning was presented as the maternal figure to whom Beethoven turned "as a son would come to his mother for aid and counsel” (66). Conversely, a range of other strategies were additionally invoked in Upton's chapter on Handel, including discussion of his patronage by female aristocrats (52-53) and the attention he received 
from women throughout his career (56). Most significantly, Upton commented that Handel "had no passion except for music" (57), and that "As he became more absorbed in his compositions he cut loose from all society” (56), words that resonated with the personality traits by which Upton was to rationalize Beethoven’s absence of a wife in the very next chapter.

The concluding section of Upton's book addressed the matter of women as “the interpreter of music,” which, while it modestly acknowledged females who had attained success in instrumental performance (203-4), focussed predominantly on high-profile singers of the eighteenth and nineteenth century. Certain Anglo-American leanings are again evident in this discussion, which opens with the notorious Faustina-Cuzzoni rivalry (188-9), and in which issues such as singers active in London, and the interpretation of the vocal output of Handel and Haydn, are prominent thereafter. Its emphasis on song likewise resonates with previous chapters, in which Upton had identified the period immediately prior to marriage with large quantities of vocal music in both Schumann’s (133) and Weber’s output, writing of the later that with the formal announcement of his engagement to his wife, "his creative power reasserted itself, and song after song came from his pen, inspired by her love” (173). In aligning women so closely not with performance but specifically with singing, which he described as "specially the province of woman $[. .$.$] a realm where her sway will always be undisputed” (200), Upton sidelined their$ contribution to music still further, confining it to a domain in which they had a unique role to play in interpreting music specifically written for female voices and characters. The act of singing is also fundamentally reliant on the natural talent of making music with one's bodily instrument, as opposed to the learned skill of performance $a t$ an instrument, and hence may have posed less of an implicit threat to the musical canon of composition. 
Confirmation of this cultural trope is to be found in the vignette on Schumann, which explicitly talked in terms of composition as being the "higher career" (132) relative to performance. It is surely no coincidence that it was in this chapter that the argument was rehearsed, Clara Schumann having been one of the best-known female composers of the nineteenth century; while briefly touching on this aspect of her activity in a passage newly inserted in the second edition (128-9), Upton's understanding of the division of musical labour between the sexes is clear from the outset of his discussion of her and her husband: "If he were a creator by the divine right of genius, by the same divine right she has been the interpreter" (1256). She was also one of only two women cited in the opening section of the volume (the other being Fanny Hensel; Upton referred to both by their married names), in which the author sought to address the question as to why, to borrow his words, "woman has failed to create important and enduring works in music” (18) (a claim made even as his appendix listed over 40 "prominent female composers” past and present [209]). The various possible reasons cited by Upton (24-9) - women's presumed lesser capacity to endure setbacks, the devotion of their time to other (familial) responsibilities, the ceasing of their musical endeavours prematurely, and so forth - are perhaps not unsurprising in themselves. But his overriding point, commonly expressed in writings of the day, concerned the perception of women as possessing an innate vessel-like capacity merely to embody music; his particular view on the topic was that, whereas men were able to control their emotions and to channel them in acts of composition, women's supposedly unbounded emotional nature meant that "In woman they are the dominating element, and so long as they are dominant she absorbs music” (23-4). On one hand, then, Upton’s volume represented a robust defence of women's place in music history as being of "equal glory and fame" to the Great Composers for having inspired some of their loftiest works and furthered their art (205). 
On the other, it undertook significant cultural work in reinforcing the fiercely male-centred nature of the musical canon through establishing women as being destined only to be the stimulant for, and interpreter of, great compositions, but apparently lacking the ability to originate them.

Published in Boston in its first edition and (like most of his volumes) by A.C. McClurg of Chicago in its second, Upton's text yields valuable insights into North American intellectual perspectives on European art-music. Sophie Fuller (1998: 115) has noted the interest generated in Britain by writings on women and music specifically from the US, Upton's publication having closely followed Fanny Raymond Ritter's pamphlet-style Woman as a Musician (1876), with which it only tangentially intersected given the very different approaches taken to the same broad subject; and it was itself succeeded, a generation later, by Rupert Hughes's The Love Affairs of Great Musicians (1904). Nonetheless, such enquiries reflect wider Trans-Atlantic preoccupations in musical biography. During the same decade as Woman in Music, Britain had seen various articles on the subject emerge in The Musical Times, while Stephen Stratton - whose contribution to the Victorian biographical project is best demonstrated by his co-authorship of the dictionary British Musical Biography (Brown and Stratton 1897) - presented a pathbreaking paper to the Musical Association on "Woman in Relation to Musical Art” (1883). In Continental Europe, Édouard Schuré’s Femmes inspiratrices et poètes annonciateurs (1908), abridged and translated ten years later as Woman: The Inspirer, while not an exclusively musical biography, featured discussion of Wagner, Mathilde Wesendonck, and Cosima Liszt (von Bülow). It was at around this time that a body of dedicated writings on women composers also started to appear, spearheaded by Otto Ebel’s landmark dictionary (1902, subsequently translated into French), heralding the sporadic tradition in musical biography of celebrating women's contribution in its 
own right that ultimately led to The Norton/Grove Dictionary of Women Composers (Sadie and Samuel 1995).

\section{Conclusion}

The nineteenth century's crucial role in the establishment of strong traditions of musical biography, and of the discipline of musicology more generally, resulted in a remarkable intellectual legacy that laid strong foundations for subsequent developments up to the present. Several significant projects of the last century, indeed, represent either the direct continuation or the completion of previously inaugurated initiatives: Thayer's biography of Beethoven was finished by Deiters and Riemann (1907-8), and subsequently revised by Forbes (1964); Botstiber contributed the third and final volume (1927) to Pohl’s biography of Haydn; and Jahn’s “definitive” biography of Mozart was so substantially reworked by Abert (1919-21) that the result was effectively a new text. That such major undertakings sought to emulate older models illustrates the extent to which the genre of musical biography was steeped in, and hence perpetuated, nineteenth-century traditions and their associated values. Likewise, seminal projects such as Grove's Dictionary of Music and Musicians (now Grove Music Online) and the "Master Musicians” series have retained major importance to modern musicology in their most recent iterations, both now under the aegis of Oxford University Press.

The latter in particular exemplifies the emergence of the so-called "scholarly biography," which places renewed emphasis on academic rigour and factual accuracy, across the course of the century. The "Master Musicians” venture had been inaugurated as a set of "popular” biographies, a genre that has nonetheless continued to flourish in the twentieth century in a broadly analogous vein to Crowest's entertaining (but not especially learned) contributions to the 
Victorian biographical project. Yet the series' more recent contributions have been solicited from leading academic authorities on their subjects, yielding important scholastic advancements within the discipline. While musicology and biography seem largely to have fallen out of favour with one another for much of the past century, the recent involvement of high-profile researchers in the latter has ensured the longevity of endeavours to write monumental "definitive" lives, with manifestations such as Landon's exhaustive five-volume study of Haydn (1976-80) itself having established the agenda for future biographical writing on that composer (see Webster 1982). Evidencing the strength of the genre's ongoing relationship with original archival research and its indebtedness to documentary sources, nineteenth-century formats such as the life-and-letters biography and published collections of letters and diaries found their inevitable zenith in the “documentary biographies” of Otto Erich Deutsch on Schubert (1946), Handel (1955), and Mozart (1965). Such initiatives constituted compilations of the very archival sources and personal documentation that remain staples of life-writing in general, and hence represented substantial contributions to scholarship on their respective subjects.

The life-and-works format epitomized by projects such as the "Master Musicians" series, together with biography’s sustained position at the forefront of musical scholarship, has led ultimately to the emergence of the modern "critical biography," which explicitly seeks to account for the subject's output with reference to corresponding points in their life story. The development of interpretive strategies by which music, even interrogated analytically at the level of the scores themselves, may be read in the light of the subject's biographical circumstances and their associated sociocultural resonances, is also fundamental to the epistemic shift within the discipline towards increased contextualization and ideology critique, influenced by scholarly movements such as the New Musicology. One notable offshoot of this intellectual trend, the 
advent of the feminist musicology, is particularly pertinent to the pattern into which female characters were historically cast in biographical narratives on the Great Composers, explored above in relation to Upton's Woman in Music. The legacy of this cultural trope has assumed a number of different guises in more recent life-writing. Upton's relational format, for instance, yielded an antecedent for such extensive projects as Bowen's dual biography of Tchaikovsky and Nadezhda von Meck (1937). The preoccupation with writing about male composers through the lens of the women whose lives intersected with, and influenced, their own has persisted to the present time in the continued interest in figures including Beethoven's enigmatic "Immortal Beloved,” as well as Clara Schumann in connection with both her husband and Brahms. It is also apparent from the ongoing, and sometimes disproportionate, fascination with composers' private lives evident from "popular” biographical writings such as Howitt’s Love Lives of the Great Composers (1995), a topic that proved so alluring as to have spawned two follow-up books by the same author.

At the same time, the field of music has proven largely unaffected by certain major currents that have characterized the advancement of the genre of biography in the twentieth century through critically challenging the central tenets of the nineteenth. The emergence of “debunking biography” heralded by the work of the Bloomsbury Group and specifically by Lytton Strachey's Eminent Victorians (1918), an assault on the hagiographical vein of much nineteenth-century life-writing, has never exerted substantial impact on musical biography, although texts such as Brown's biography on Schubert (1958) start to touch on this phenomenon for its detailed scrutiny of many of the more unlikely stories with which the composer has traditionally been associated. A related trend is the rise of revisionist biography, which strives not merely to address the naiveties of earlier authors, but also to offer radical new perspectives 
on specific subjects that portray them in an altogether different light from previous biographical undertakings; the paradigmatic example in recent decades is Volkov's publication of Shostakovich's memoirs as Testimony (Shostakovich 1979), which sent shockwaves through the practice of life-writing on the composer, leaving it deeply divided thereafter.

The twentieth century also witnessed the introduction of a psychological dimension to biography, again traceable to the Bloomsbury Group since James and Alix Strachey (Lytton’s younger brother and sister-in-law) were among the first English translators of Freud's works, published by Leonard and Virginia Woolf's Hogarth Press. Within musicology, such approaches are perhaps most associated with the "psychobiography" exemplified by Maynard Solomon, notably in his landmark volume on Beethoven (1977); the impact of Solomon's groundbreaking contributions to biographical scholarship has been sufficient to destabilize certain aspects of modern musicology, not least in relation to his claims made regarding Schubert’s sexuality (1989). Musical biography has also proven highly receptive to the possibilities opened up by the advent of broadcast media, not least in the emergence of the dramatized or fictionalized composer biopic (see, for example, Tibbetts 2005) epitomized by such classic contributions as Miloš Forman’s Amadeus (1984), based on Peter Shaffer’s play (1980). Such endeavours, coupled to the ongoing public captivation with composers' lives nurtured by the genres of the radio and television documentary, might reasonably be considered the modern progenitors of both the historical "popular" biography as well as an additional subcategory that has fallen beyond the scope of this survey, the novelized or fictional biography.

While life-writing on musical subjects has not been entirely unreceptive to twentiethcentury developments, then, neither has it wholeheartedly embraced them. That it has not sought in any substantive manner to strike its greatest biographical heroes from their pedestals is 
indicative of the resilience of what has always been a comparatively small canon, for which there is therefore a heightened need for preservation relative to other disciplines. Its robustness illustrates the extent to which intellectual culture has persisted in cherishing both its major figures, and the fanciful anecdotes with which they have traditionally been associated, as inherited from the nineteenth-century practices of “popular” biography represented by Crowest’s collection. Likewise, as I have elsewhere argued, musicology's increased adoption in recent decades of more inclusive perspectives such as feminism, an avenue of investigation itself prefigured by Upton's volume, demonstrates a lasting indebtedness to the same nineteenthcentury assumptions and preoccupations that much of this scholarship has simultaneously sought to challenge (Wiley 2010). The extent to which modern musical thought remains grounded in the nineteenth century in relation to life-writing highlights the importance of continuing rigorously to dismantle both the ideologies of musical biography of the past and the enduring legacy of its foundational cultural contribution, in order to activate new directions for future musicological enquiry. 


\section{Musical Biography: Timeline of Selected Major Publications of the Long Nineteenth Century}

\section{Pre-1790}

C.P.E. Bach and J.F. Agricola, Obituary of J.S. Bach [Nekrolog] (1754)

John Mainwaring, Memoirs of the Life of the Late George Frederic Handel (1760) [Ger. trans., 1761]

\section{0s}

Ernst Ludwig Gerber, Historisch-biographisches Lexikon der Tonkünstler, 2 vols. (1790-2)

Friedrich Schlichtegroll, “Johannes Chrysostomus Wolfgang Gottlieb Mozart” (1793)

Franz Xaver Niemetschek, Leben des K.K. Kapellmeisters Wolfgang Gottlieb Mozart (1798, 2/1808) [Eng. trans., 1956]

Friedrich Rochlitz, “Verbürgte Anekdoten aus Wolfgang Gottlieb Mozarts Leben” (1798-1801)

\section{0s-1810s}

Johann Nicolaus Forkel, Über Johann Sebastian Bachs Leben, Kunst und Kunstwerke (1802) [Eng. trans., 1820]

Georg August Griesinger, Biographische Notizen über Joseph Haydn (1810) [Eng. trans., 1963]

Albert Christoph Dies, Biographische Nachrichten von Joseph Haydn (1810) [Eng. trans., 1963]

Alexandre-Etienne Choron and François Joseph Fayolle, Dictionnaire historique des musiciens, 2 vols. (1810-11)

Giuseppe Carpani, Le Haydine (1812) [Eng. trans., 1972]

Ernst Ludwig Gerber, Neues historisch-biographisches Lexikon der Tonkünstler, 2nd edn., 4 vols. (1812-14)

Louis-Alexandre-César Bombet [Stendhal], Lettres écrites de Vienne en Autriche [Lives of Haydn, Mozart, and Metastasio] (1814)

\section{0s}

Stendhal, Vie de Rossini (1824) [Eng. trans., 1956]

John S. Sainsbury, A Dictionary of Musicians From the Earliest Times, 2 vols. (1825)

Michael Kelly, Reminiscences of Michael Kelly, 2 vols. (1826)

Giuseppe Baini, Memorie storico-critiche della vita e delle opere di Giovanni Pierluigi da Palestrina, 2 vols. (1828)

Georg Nikolaus von Nissen, Biographie W.A. Mozart's, 2 vols. (1828)

\section{0s}

Carl von Winterfeld, Johannes Pierluigi von Palestrina (1832)

Carl von Winterfeld, Johannes Gabrieli und sein Zeitalter, 3 vols. (1834) 
Gustav Schilling, Encyclopädie der gesammten musikalischen Wissenschaften oder Universal Lexikon der Tonkunst, 7 vols. (183542)

F.-J. Fétis, Biographie universelle des musiciens, 8 vols. (1835-44, 2/1860-5)

Franz Gerhard Wegeler and Ferdinand Ries, Biographische Notizen über Ludwig van Beethoven (1838, 2/1845) [Eng. trans., 1987]

\section{0s-1850s}

Anton Schindler, Biographie von Ludwig van Beethoven, 2 vols. (1840) [Eng. trans., 1841]

W.A. Lampadius, Felix Mendelssohn-Bartholdy: Ein Denkmal für seine Freunde (1848) [Eng. trans., 1865]

F. Liszt (attrib.), F. Chopin (1852) [Eng. trans., 1899]

Otto Jahn, Wolfgang Amadeus Mozart, 4 vols. (1856-9)

Victor Schœlcher, The Life of Handel (1857)

Wilhelm Joseph von Wasielewski, Robert Schumann: Eine Biographie (1858) [Eng. trans., 1871]

Friedrich Chrysander, G.F. Händel, 3 vols. (1858-67)

\section{0s}

Anton Schindler, Biographie von Ludwig van Beethoven, 3rd edn., 2 vols. (1860) [Eng. trans., 1966]

Ludwig Nohl, Mozart (1863, 2/1877 as Mozart's Leben) [Eng. trans., 1877]

Ludwig Nohl, Beethoven's Leben, 3 vols. (1864-77)

Heinrich Kreissle von Hellborn, Franz Schubert (1865) [Eng. trans., 1869]

Richard Wagner, Mein Leben, 2 vols. (written 1865-80, publ. 1911) [Eng. trans., 1911]

Alexander Wheelock Thayer, Ludwig van Beethovens Leben, 5 vols.; vols. 1-3 (1866-79) [see Deiters and Riemann (1907-8) for

Eng. trans.]

La Mara, Musikalische Studienköpfe, 5 vols. (1868-1882)

\section{0s}

Hector Berlioz, Mémoires (publ. 1870) [Eng. trans., 1969]

Philipp Spitta, Johann Sebastian Bach, 2 vols. (1873-80) [Eng. trans., 1884-5]

Edward Bellasis, Cherubini: Memorials Illustrative of his Life (1874)

C.F. Pohl, Joseph Haydn, 3 vols.; vols. 1-2 (1875-82)

C.F. Glasenapp, Richard Wagner's Leben und Wirken, 2 vols. (1876-7, 3/1894-1911) [Eng. rev. and trans., 1900-8]

Moritz Karasowski, Friedrich Chopin: Sein Leben, seine Werke und Briefe, 2 vols. (1877) [Eng. trans., 1879]

George Grove (ed.), A Dictionary of Music and Musicians, 4 vols. (1878-90) 


\section{0s-1890s}

Hermann Deiters, Johannes Brahms (1880, 2/1898) [Eng. trans., 1888]

Francis Hueffer (ed.), “The Great Musicians” series, 14 vols. (1881-90)

C. Hubert H. Parry, Studies of Great Composers (1886)

Frederick Niecks, Frederick Chopin as a Man and Musician, 2 vols. (1888)

La Mara (ed.), Franz Liszt's Briefe, 8 vols. (1893-1905)

Heinrich Reimann (ed.), "Berühmte Musiker” series, 20+ vols. (from 1897)

Frederick J. Crowest (ed.), “The Master Musicians” series, 12 vols. (1899-1906)

\section{0s}

Theodore Baker, A Biographical Dictionary of Musicians (1900)

Robert Eitner, Biographisch-bibliographisches Quellen-Lexikon der Musiker und Musikgelehrten, 10 vols. (1900-4)

J.A. Fuller Maitland (ed.), Grove's Dictionary of Music and Musicians, 2nd edn., 5 vols. (1904-10)

Max Kalbeck, Johannes Brahms, 4 vols. (1904-14)

Florence May, The Life of Johannes Brahms, 2 vols. (1905)

Élie Poirée (ed.), "Les musiciens célèbres” series, 30+ vols. (from 1905)

Hermann Deiters and Hugo Riemann, Ludwig van Beethovens Leben, vols. 4-5 [of Thayer] (1907-8) [Eng. trans., 1921]

\section{Post-1910}

Hermann Abert, W.A. Mozart, 2 vols. (1919-21) [after Jahn]

Hugo Botstiber, Joseph Haydn (1927) [vol. 3 of Pohl] 


\section{Reference List}

Bashford, Christina. 2003. “Not Just 'G.': Towards a History of the Programme Note.” In George Grove, Music and Victorian Culture edited by Michael Musgrave. 115-42. Basingstoke. Palgrave Macmillan.

Bonds, Mark Evan. Forthcoming. "Music as Autobiography.” In Musical Biography: Ideology, Narrative, and Myth edited by Christopher Wiley and Paul Watt.

Bowen, Catherine Drinker and Barbara von Meck. Beloved Friend: The Story of Tchaikowsky and Nadejda von Meck. London. Hutchinson, 1937.

Bower, Bruno. 2016. “The Crystal Palace Saturday Concerts, 1865-1879: A Case Study of the Nineteenth-Century Programme Note.” PhD dissertation. Royal College of Music, London.

Brown, James D. and Stephen S. Stratton. 1897. British Musical Biography: A Dictionary of Musical Artists, Authors and Composers, born in Britain and its Colonies. Birmingham. Stratton.

Brown, Maurice J.E. 1958. Schubert: A Critical Biography. London. Macmillan.

Burney, Charles. 1776-89. A General History of Music, from the Earliest Ages to the Present Period. 4 vols. London. Author.

Carlyle, Thomas. 1841. On Heroes, Hero-Worship, and the Heroic in History: Six Lectures. London. Fraser.

[Cox, J.E.] 1872. Musical Recollections of the last Half-Century. 2 vols. London. Tinsley.

Crowest, F. 1874. The Great Tone-Poets: Being Short Memoirs of the Greater Musical Composers. London. Bentley.

Crowest, Frederick. 1878. A Book of Musical Anecdote, From every available Source. 2 vols. London. Bentley.

Crowest, Frederick J. 1890. Cherubini. London. Sampson Low.

Crowest, Frederick J. 1895. The Dictionary of British Musicians: From the Earliest Times to the Present. London. Jarrold.

Crowest, Frederick J. 1897. Verdi: Man and Musician: His Biography with Especial Reference to his English Experiences. London. Milne.

Crowest, Frederick J. 1899. Beethoven. London. Dent.

Crowest, Frederick J. 1902. Musicians’ Wit, Humour, and Anecdote. London. Scott. 
Deaville, James. 2006. “This Is (Y)our Life: (Re)Writing Women’s Autobiographies in Music in Nineteenth-Century Germany.” In Musical Biography: Towards New Paradigms edited by Jolanta T. Pekacz. 135-58. Aldershot. Ashgate.

Deutsch, Otto Erich. 1946. Schubert: A Documentary Biography translated by Eric Blom. London. Dent.

Deutsch, Otto Erich. 1955. Handel: A Documentary Biography. London. Black.

Deutsch, Otto Erich. 1965. Mozart: A Documentary Biography translated by Eric Blom, Peter Branscombe, and Jeremy Noble. London. Black.

Ebel, Otto. 1902. Women Composers: A Biographical Handbook of Woman's Work in Music. Brooklyn. Chandler.

Fétis, F.-J. 1869-76. Histoire générale de la musique depuis les temps les plus anciens jusqu'à nos jours. 5 vols. Paris. Firmin-Didot.

Forbes, Elliot. 1964, rev./1967. Thayer's Life of Beethoven. 2 vols. Princeton, NJ. Princeton University Press.

Fuller, Sophie. 1998. "Women Composers during the British Musical Renaissance, 1880-1918." PhD dissertation. University of London.

Gotwals, Vernon. trans. and ed. 1963. Joseph Haydn: Eighteenth-Century Gentleman and Genius. Madison. University of Wisconsin Press.

Harasowski, Adam. 1967. The Skein of Legends Around Chopin. Glasgow. MacLellan.

Hawkins, Sir John. 1776. A General History of the Science and Practice of Music.

5 vols. London. Payne.

Howitt, Basil. 1995. Love Lives of the Great Composers, from Gesualdo to Wagner. Toronto. Sound and Vision.

Hughes, Rupert. 1904. The Love Affairs of Great Musicians. 2 vols. Boston. Page.

Landon, H.C. Robbins. 1976-80, 2/1994. Haydn: Chronicle and Works. 5 vols. [London]. Thames and Hudson.

Lenneberg, Hans. 1988. Witnesses and Scholars: Studies in Musical Biography. New York. Gordon and Breach.

Moscheles, Charlotte. 1873. Life of Moscheles, with selections from his diaries and correspondence translated by A.D. Coleridge. 2 vols. London. Hurst and Blackett. 
Nadel, Ira Bruce. 1984. Biography: Fiction, Fact and Form. London. Macmillan.

Pekacz, Jolanta T. 2004. "Memory, History and Meaning: Musical Biography and its Discontents.” Journal of Musicological Research 23.1: 39-80.

Peters, Catherine. 1995. "Secondary Lives: Biography in Context.” In The Art of Literary Biography edited by John Batchelor. 43-56. Oxford. Clarendon.

Ritter, Fanny Raymond. 1876. Woman as a Musician: An Art-Historical Study. New York. Schuberth.

Rose, Jonathan. 2001. The Intellectual Life of the British Working Classes. New Haven, CT. Yale University Press.

Sadie, Julie Anne and Samuel, Rhian. eds. 1995. The Norton/Grove Dictionary of Women Composers. New York. Norton.

Schlaeger, Jürgen. 1995. “Biography: Cult as Culture.” In The Art of Literary Biography edited by John Batchelor. 57-71. Oxford. Clarendon.

Schuré, Édouard. 1908. Femmes inspiratrices et poètes annonciateurs. Paris. Perrin. Abridged as Woman: The Inspirer translated by Fred Rothwell. 1918. London. Power-Book.

Scott, Derek B. 2003. From the Erotic to the Demonic: On Critical Musicology. Oxford. Oxford University Press.

Shostakovich, D. 1979. Testimony: The Memoirs of Dmitri Shostakovich as Related to and Edited by Solomon Volkov translated by Antonina W. Bouis. London. Hamilton.

Solomon, Maynard. 1977, 2/1998. Beethoven. New York. Schirmer.

Solomon, Maynard. 1989. "Franz Schubert and the Peacocks of Benvenuto Cellini." $19^{\text {th }}$-Century Music 12.3: 193-206.

Solomon, Maynard. 2001. "Biography.” In The New Grove Dictionary of Music and Musicians edited by Stanley Sadie. 2nd edn. 29 vols. iii.598-601. London. Macmillan.

Strachey, Lytton. 1918. Eminent Victorians: Cardinal Manning - Florence Nightingale - Dr. Arnold - General Gordon. London. Chatto and Windus.

Stratton, Stephen S. 1883. "Woman in Relation to Musical Art.” Proceedings of the Musical Association 9: 115-46.

Tibbetts, John C. 2005. Composers in the Movies: Studies in Musical Biography. New Haven, CT. Yale University Press. 
Upton, George P. 1880, 2/1886. Woman in Music: An Essay. Boston. Osgood. 2/Chicago. McClurg.

Upton, George P. 1886. The Standard Operas: Their Plots, Their Music, and Their Composers. Chicago. McClurg.

Upton, George P. 1889. The Standard Symphonies: Their History, Their Music, and Their Composers. Chicago. McClurg.

Upton, George P. 1908. Musical Memories: My Recollections of Celebrities of the Half Century, 1850-1900. Chicago. McClurg.

Upton, George P. 1909. Standard Concert Repertory and Other Concert Pieces. Chicago. McClurg.

Upton, George P. 1910. Standard Musical Biographies: A Handbook Setting forth the Lives, Works, and Characteristics of Representative Composers. Chicago. McClurg.

Upton, George P. 1915. The Song: Its Birth, Evolution, and Functions. Chicago. McClurg.

Webster, James. 1982. "Prospects for Haydn Biography after Landon.” The Musical Quarterly 68.4: 476-95.

Wiley, Christopher. 2003. “'A Relic of an Age Still Capable of a Romantic Outlook’: Musical Biography and The Master Musicians Series, 1899-1906.” Comparative Criticism 25: 161-202.

Wiley, Christopher. 2008. “Re-writing Composers’ Lives: Critical Historiography and Musical Biography.” 2 vols. PhD dissertation. University of London.

Wiley, Christopher. 2010. "Biography and the New Musicology.” In (Auto)Biography as a Musicological Discourse edited by Tatjana Markovic and Vesna Mikic. 3-27. Belgrade. Fakultet Muzicke Umetnosti.

Wiley, Christopher. 2013. "Mythological Motifs in the Biographical Accounts of Haydn's Later Life.” In The Land of Opportunity: Joseph Haydn in Britain edited by Richard Chesser and David Wyn Jones. 195-211. London. The British Library.

Wiley, Christopher. 2015. "Musical Biography and the Myth of the Muse.” In Critical Music Historiography: Probing Canons, Ideologies, and Institutions edited by Vesa Kurkela and Markus Mantere. 251-61. Farnham. Ashgate.

Wiley, Christopher. Forthcoming. Musical Biography as a Historical and Literary Genre: The Master Musicians Series, 1899-1906.

Wiley, Christopher and Paul Watt. eds. Forthcoming. Musical Biography: Ideology, Narrative, and Myth. 
Zon, Bennett. 2017. Evolution and Victorian Musical Culture. Cambridge. Cambridge University Press. 